\section{ABCS}

How to cite this article: Hattori et al. Risk factors influencing food habits of overweight and obese incarcerated women. ABCS Health Sci. 2020;45:e020020. https://doi. org/10.7322/abcshs.45.2020.1366

Received: Oct 14, 2019

Revised: Mar 05, 2020

Approved: Mar 30, 2020

Corresponding author: Ana Cláudia Pereira Terças Trettel - Universidade do Estado de Mato Grosso - Avenida Inácio Bittencourt Cardoso, Km 07 (s/n) - Jardim Aeroporto CEP: 78300-000 -Tangará da Serra (MT), Brasil - E-mail: ana.claudia@unemat.br

Declaration of interests: nothing to declare Funding: Fundação de Amparo à Pesquisa do Estado de Mato Grosso (FAPEMAT). Edital PPSUS 003/2017, Process Number $285300 / 2018$

This is an open access article distributed under the terms of the Creative Commons Attribution License

(C) 2020 Hattori et al.

\title{
Risk factors influencing food habits of overweight and obese incarcerated women
}

\author{
Thalise Yuri Hattori ${ }^{1}$, Edilaene de Oliveira Silva1, Vagner Ferreira do Nascimento, \\ Marina Atanaka ${ }^{2}$, Ana Claudia Pereira Terças Trettel ${ }^{1,2}$ \\ 'Departamento de Enfermagem, Universidade do Estado do Mato Grosso (UNEMAT), Tangará da \\ Serra (MG), Brasil. \\ ${ }^{2}$ Programa de Pós-Graduação em Saúde Coletiva, Universidade Federal de Mato Grosso (UFMT) - \\ Cuiabá (MT), Brasil.
}

\begin{abstract}
Introduction: Chronic diseases stand out on the world stage due to the impact they cause on population morbidity and mortality. In the case of persons deprived of their liberty, the situation is intensified by the restriction in the choice of food and access to physical exercise. Objective: To identify the risk factors that influence the eating habits of overweight and obese incarcerated women. Methods: Cross-sectional study, conducted with 31 participants. Data collection took place in the second half of 2018, comprising individual interviews of incarcerated women using a semi-structured questionnaire and measurement of anthropometric measures. The data were systematized in electronic spreadsheets and statistical analysis was performed in a descriptive way. The study complied with ethical standards from national guidelines. Results: A greater prevalence of overweight and obesity was identified in young, multiparous women, with low education and lower income. Most used tobacco and had less than a year in prison. Despite being overweight and obese, they felt good about their body, which may be reflecting on their lifestyle, through sedentary lifestyle, self-care deficit and consumption of products and foods with low nutritional value. Conclusion: Overweight and obesity are multifactorial and are not related only to behavioral aspects. It is necessary to carry out new research approaches that clarify the health weaknesses in prison, making it possible to provide a better quality of life for this population group.
\end{abstract}

Keywords: women's health; prisons; obesity.

\section{INTRODUCTION}

In recent years, excess body weight (overweight and obesity) has gained prominence in the international and national scope, becoming a public health problem. It is estimated that there was an increase in the number of overweight and obese individuals from 921 million in 1980 to 2.1 billion in $2013^{1}$. The latest research conducted in Brazil also shows important growth and points to alarming findings, in which about $20 \%$ of the population is obese and $55 \%$ overweight. The highest prevalence of obesity was found in the capitals of Campo Grande, Cuiabá, Belém, Porto Alegre and Maceió, especially among women ${ }^{2}$.

Such a condition predisposes to several risk factors that become an aggravating factor for the health condition, such as hypertension, diabetes, neoplasms, strokes, among 
others $^{3}$. This increase in weight is related to factors such as physical inactivity, insufficient physical activity, unhealthy diet with a high content of fats and carbohydrates, smoking, drinking, in addition to genetic, metabolic, hormonal, environmental, behavioral, cultural and social factors ${ }^{4,5}$.

In addition, women have other causes for weight imbalance, such as hormonal, gestational and psycho-emotional aspects that can negatively affect their health condition ${ }^{6}$. And when these women are in the condition of incarceration, these risks are amplified, either by the new dynamics of life established or by the behaviors acquired collectively. It is important to highlight that when they are in prison, the break with the outside world and the new internal institutional/organizational rules distance them from the usual appearance and the perception of themselves as a woman, which consequently causes losses in self-image, self-esteem and self-care ${ }^{7}$.

These psychosocial issues ${ }^{8,9}$ added to current environmental conditions and past life habits ${ }^{10,11}$, make this problem multifactorial and deserving more attention from health professionals, especially from prison system managers.

It is observed that data on nutritional status in incarcerated women are scarce in the literature, the few existing researches confirm the increase in these indexes, attributing only the behavioral factors to these disorders ${ }^{11}$. As food is one of the most affected aspects during incarceration, we sought to know the risk factors that influence the eating habits of overweight and obese reeducated women in the public chain of the Middle North of Mato Grosso, Brazil. This proposal in Mato Grosso is innovative and pioneering and is fundamental to support the approach and understanding of this theme.

Based on that, the objective was to identify the risk factors that influence the eating habits of overweight and obese incarcerated women.

\section{METHODS}

This is a cross-sectional study, carried out in a public female prison in Mato Grosso. The site has a capacity for up to 60 incarcerated women who are distributed in eight cells. Because it is a reference facility, it serves several municipalities in the state and surrounding states.

Inclusion criteria were women older than 18 years old on a provisional detention basis or not, with overweight or obesity. Incarcerated women in isolation or newly admitted and pregnant women were excluded. The sampling was of the census type and by convenience.

Data collection took place in the second half of 2018, through an individual interview using a semi-structured questionnaire prepared by the researchers. Each interview lasted approximately 30 minutes, followed by the measurement of anthropometric data (weight and height).
Regarding the measurement of anthropometric measurements, for the definition of body weight, the portable electronic anthropometric scale (model Línea, Kratos-Cas, São Paulo, Brazil) was used and for height verification, the stadiometer (model Microtoise Setup) was used, CMS Weighing Equipment Ltd., London, UK). The techniques for measuring weight and height respected the technical standard of the Food and Nutrition Surveillance System (Sisvan) of the Brazilian Ministry of Health ${ }^{12}$. For classification of nutritional status, the body mass index $\left(\mathrm{BMI}, \mathrm{kg} / \mathrm{m}^{2}\right)$ was used. The values defined by the World Health Organization were classified as cut-off points ${ }^{13}$.

The data were systematized in electronic spreadsheets in double typing, later checked and the possible typing mistakes were corrected. After the end of the conference and construction of the bank, the import to the Statistical Package for the Social Sciences (SPSS) version 20.0 was performed for specific analyzes. Descriptive statistical analysis was performed and presented by graphs and tables of distribution of absolute and relative frequency.

The study was approved by the Human Research Ethics Committee of the Universidade do Estado de Mato Grosso, under CAAE: 50417815.8.0000.5166 and opinion 1,457,621/2016. All ethical aspects of research involving human beings were met and respected in accordance with CNS Resolution 466/2012. It is noteworthy that all women were informed of the risks and benefits of the study and signed the informed consent form to participate in this study.

\section{RESULTS}

The study included 31 women, with a mean age of 32.5 years (standard deviation \pm 10.1 years), with a predominance of brown color/race $(71.0 \%)$, married or in a stable relationship (54.8\%), without occupation (29.8\%). Of these, $51.6 \%$ were overweight and $48.4 \%$ were obese.

The following data were organized according to the hierarchy in relation to the issue of overweight and obesity. At the distal level, the youngest age group up to 30 years old (48.4\%) predominated, but there was a highlight in the intermediate age group of 31-44 years old (53.3\%) for obese women. In terms of education, most have incomplete primary education (42.0\%), 67.7\% have low family income (1-2 minimum wages), with obese women with lower earnings $(80.0 \%)$. As for parity, they have three or more children (57.7\%) (Table 1).

At the intermediate level, most use tobacco (58.1\%), have been incarcerated for less than twelve months (58.1\%). A higher percentage of obesity was also observed for those who had been in detention for a longer period (46.7\%). As for body image, both groups were satisfied with their body even though they were overweight and obese (54.8\%). 
Table 1: Risk factors associated with overweight and obesity in a female prison sample from a municipality in the middle north of the state of Mato Grosso, Brazil, 2018.

\begin{tabular}{|c|c|c|c|c|}
\hline \multicolumn{2}{|l|}{ Variables } & $\begin{array}{l}\text { Overweight } \\
\text { n (\%) }\end{array}$ & $\begin{array}{c}\text { Obese } \\
\text { n (\%) }\end{array}$ & Total \\
\hline \multirow{3}{*}{ Age } & Up to 30 years & $10(62.5)$ & 5 (33.3) & 15 (48.4) \\
\hline & $31-44$ years & $5(31.3)$ & $8(53.3)$ & $13(41.9)$ \\
\hline & $45-59$ years & $1(6.2)$ & $2(13.4)$ & $3(9.7)$ \\
\hline \multirow{5}{*}{ Education* } & Incomplete ES & $3(18.8)$ & $10(66.7)$ & $13(42.0)$ \\
\hline & Complete ES & $9(56.3)$ & $3(20.0)$ & $12(38.7)$ \\
\hline & Incomplete HS & $2(12.5)$ & $2(13.3)$ & 4 (12.9) \\
\hline & Complete HS & $1(6.2)$ & - & $1(3.2)$ \\
\hline & Incomplete $\mathrm{HE}$ & $1(6.2)$ & - & $1(3.2)$ \\
\hline \multirow{3}{*}{$\begin{array}{l}\text { Monthly } \\
\text { family } \\
\text { income }\end{array}$} & 1-2 MW & $9(56.3)$ & $12(80.0)$ & $21(67.7)$ \\
\hline & 3-4 MW & $1(6.2)$ & $1(6.6)$ & $2(6.5)$ \\
\hline & 5-6 MW & $6(37.5)$ & $2(13.4)$ & $8(25.8)$ \\
\hline \multirow{3}{*}{$\begin{array}{l}\text { Number of } \\
\text { children }\end{array}$} & 1 & $3(25.0)$ & $3(21.4)$ & $6(23.1)$ \\
\hline & 2 & $2(16.7)$ & $3(21.4)$ & $5(19.2)$ \\
\hline & 3 or more & $7(58.3)$ & $8(57.2)$ & 15 (57.7) \\
\hline \multirow{2}{*}{ Tobacco } & Yes & $11(68.8)$ & 7 (46.7) & $18(58.1)$ \\
\hline & No & $5(31.2)$ & $8(53.3)$ & $13(41.9)$ \\
\hline \multirow{3}{*}{$\begin{array}{l}\text { Detention } \\
\text { time }\end{array}$} & $<12$ months & $11(68.8)$ & 7 (46.7) & $18(58.1)$ \\
\hline & $12-23$ months & $4(25.0)$ & $1(6.6)$ & $5(16.1)$ \\
\hline & $\geq 24$ months & $1(6.2)$ & $7(46.7)$ & $8(25.8)$ \\
\hline \multirow{2}{*}{$\begin{array}{l}\text { Feels good } \\
\text { with the body }\end{array}$} & Yes & $9(56.3)$ & $8(53.3)$ & $17(54.8)$ \\
\hline & No & $7(43.7)$ & $7(46.7)$ & $14(45.2)$ \\
\hline \multirow{2}{*}{$\begin{array}{l}\text { Recreational } \\
\text { activity }\end{array}$} & Active & - & $1(6.7)$ & $1(3.2)$ \\
\hline & $\begin{array}{l}\text { Insufficient } \\
\text { active/Inactive }\end{array}$ & $16(100.0)$ & 14 (93.3) & $30(96.8)$ \\
\hline \multirow{2}{*}{ TV use } & Yes & $14(87.5)$ & $13(86.7)$ & 27 (87.1) \\
\hline & No & $2(12.5)$ & $2(13.3)$ & $4(12.9)$ \\
\hline \multirow{4}{*}{$\begin{array}{l}\text { Consumption } \\
\text { of vegetables }\end{array}$} & Rarely & $2(12.5)$ & $2(13.4)$ & $4(12.9)$ \\
\hline & Sometimes & $1(6.2)$ & $8(53.3)$ & $9(29.0)$ \\
\hline & Frequently & $10(62.5)$ & 5 (33.3) & $15(48.4)$ \\
\hline & Never & $3(18.8)$ & - & $3(9.7)$ \\
\hline \multirow{3}{*}{$\begin{array}{l}\text { Items } \\
\text { received } \\
\text { during visits }\end{array}$} & $\begin{array}{l}\text { Industrialized } \\
\text { products }\end{array}$ & $4(44.5)$ & 5 (33.3) & $9(42.8)$ \\
\hline & Fruits & $1(11.1)$ & 5 (33.3) & $6(28.6)$ \\
\hline & Sweets & $1(11.1)$ & 5 (33.3) & $6(28.6)$ \\
\hline Tote & & & & $31(100.0)$ \\
\hline
\end{tabular}

ES: Elementary School; HS: High School; HE: Higher Education. MW: minimum wage of $R \$ 954,00$.

When analyzing the proximal levels, most were considered insufficient active or inactive (96.8\%), with emphasis on the overweight group. Regarding the use of television, $87.1 \%$ of reeducated women used it, and for periods that exceeded five hours a day $(63.0 \%)$.

With regard to daily food, higher consumption of vegetables (48.4\%) was reported, being more common in overweight women (62.5\%). Only $48.4 \%$ of women received visits and $42.8 \%$ of items received were industrialized products.

\section{DISCUSSION}

Food is one of the basic needs of human beings and is among one of the most affected aspects during prison, an example of this were the studies carried out in Brazilian women's prisons that demonstrated the high percentage of overweight and obesity ${ }^{10,14}$. In international surveys, a higher prevalence of obesity (48.0\%) than overweight $(39.0 \%)$ was observed among women deprived of their freedom ${ }^{11}$. In Seysse, France, women were obese when admitted and showed worsening obesity in incarceration ${ }^{15}$.

Likewise in Brazil, it appears that these women do not always develop this condition exclusively in prison, many are already overweight when entering prison, due to bad living habits (smoking, physical inactivity, use of illicit drugs) and conditions unfavorable socioeconomic conditions (unemployment, delinquency, poverty) that contribute to nutritional problems $\mathrm{s}^{8,10}$.

In addition to the aforementioned factors, there was an association of age from 40 years onwards in the female population in general with weight gain ${ }^{3,6}$. One of the reasons is attributed to hormonal changes due to aging, which cause greater accumulation of fat and changes in its distribution ${ }^{6,16}$. Hormonal changes are also common in this age group, as a consequence of hypoestrogenism, weight gain and the appearance of other symptoms such as hot flashes, night sweats and vaginal dryness, characteristic signs of menopause $^{17}$.

However, in a cohort study carried out in Pelotas, which analyzed the evolution of overweight and obesity until adulthood of men and women in general, it was found that women showed an increase in overweight of $23.2 \%$ for $57.6 \%$ at 15 years old and at 30 years old this increase was from $7.1 \%$ to $23.0 \%$ of obesity ${ }^{14}$. These findings are consistent with the nutritional transition experienced in the country ${ }^{18,19}$ in which overweight and obesity is becoming more common in the younger population, as observed in the results of the present study. From this information, it shows the importance of nutritional monitoring of these incarcerated women since they are young and overweight, they are at risk of worsening the condition and for greater health problems.

Schooling was also inversely associated with overweight in the female population in general ${ }^{14,20}$. There was a description of the relationship between low schooling and family and economic disruption, but this relationship was not evaluated in terms of nutritional classification ${ }^{11}$.

With regard to family income, the results of the present study were also similar to the findings of other studies carried out with reeducated women ${ }^{3,10}$. Insufficient family income indirectly interferes with the triggering of overweight and obesity, as the financial precariousness linked to the easy access to foods of greater energy and less nutritional value, influences the daily $\operatorname{diet}^{4}$. According to some research findings, the prediction is to be overweight and obese in subjects with low income and low education ${ }^{11,21}$, characteristics observed among the reeducated women in the present study.

The relationship between parity number and overweight in women is described in the literature, being more prevalent in 
multiparous women in the general female population ${ }^{22}$. The overweight of puerperal women in Porto Alegre was associated with the value of pre-gestational BMI $(\mathrm{p}<0.001)$, gestational weight gain $(\mathrm{p}<0.001)$ and age $\leq 20$ years $(\mathrm{p}<0.001)^{22}$. In a study carried out in weight retention after 6 months postpartum ${ }^{23}$. This relationship of weight retention after childbirth has varied from 2 months to 21 years, with excessive gestational weight gain being predictive for cases of obesity in the postpartum period. In this research, no information was collected regarding prenatal issues that could analyze the association of overweight and/or obesity with parity, with only multiparity being observed in $57.7 \%$ of participants.

Although this research does not have information about the inter-gestational period, the proximity between them is noted because it is a relatively young and multiparous population (4-7 children). Studies in Brazilian women's prisons associate multiparity only with precarious lifestyle before prison, such as poverty, non-use of contraceptives, multiple relationships and unprotected $\operatorname{sex}^{7}$ not making this relationship with being overweight. Adolescent pregnancy as well as its recurrence is associated with reproductive and socioeconomic factors, a similar situation among women deprived of their liberty. Pregnancy during adolescence is described as a risk factor with an increased prevalence of overweight and obesity in the postpartum and adult years ${ }^{24}$.

As for life habits, it is observed that the consumption of tobacco and alcohol associated with other illicit psychoactive substances are common before incarceration, with a very fine line between consumption and trafficking. The prohibition of the use of illicit drugs in the prison environment enables the greater consumption of tobacco. Similar results of this research were described in other women's prisons regarding the high consumption of tobacco ${ }^{24,25}$ in the state of Paraíba, Brazil, for example, $67.6 \%$ used it, while elsewhere in the country ${ }^{8} 26.1 \%$ had severe nicotine dependence. Although national surveys in prisons have not assessed the relationship between weight gain and tobacco, a North American study found that women with pre-incarceration who used tobacco gained more weight $(81.0 \%)$ than other women ${ }^{9}$.

It is noteworthy that in the institution studied, cigarette consumption is unrestricted, making the incarcerated woman a smoker have a greater desire to do so due to prison conditions. The restriction or decreased access to tobacco contributes to the increase in body weight, since it leads to abstinence, causing feelings of restlessness and increased appetite, often replacing the habit of smoking with eating ${ }^{26}$. It is observed that the measures of tobacco control in the last 20 years, reproduce the significant decrease of its consumption, however the same still does not happen inside the prison institutions.

Detention time is an important factor for the individual's life condition, because in the prison system life and health situations are precarious and unhealthy ${ }^{27}$. It was observed that the short period of detention (less than one year) was similar to that of other studies $^{22,28}$. Incarceration affects the family bond, as the woman in that condition ends up losing her relationship with her children and the family. Therefore, this distance implies reports of feelings of sadness, abandonment, discouragement and revolt ${ }^{7,8,29}$.

The isolation resulting from incarceration leads to the distance between family, partners and friends. For women deprived of their liberty, this issue is greater, since maternal functions are transferred to other people, failing to exercise the necessary care for their children ${ }^{8,30}$. When analyzing the nutritional situation related to weight gain and the period of imprisonment, a higher percentage of obese women $(46.7 \%)$ is observed, who coincidentally were detained for a longer time. One of the reasons may be due to the low perspective related to aspects of life and the return to post detention activities that are usually forgotten, as the long period of imprisonment makes the situation experienced increasingly inhospitable ${ }^{31}$.

In the face of an environment with no mirrors that makes it impossible for the incarcerated women to observe their own reflection, it makes them resort to the image of their companions in prison $^{31}$. As all participants in the present study are overweight or obese, therefore, there is particularly a preference for maintaining a larger body than thinner silhouettes, which is why the results showed that the majority (54.8\%) were are satisfied with the body.

This finding may be related to the most vulnerable and hostile environment in which they find themselves, where the masculinization of the body facilitates greater access to internal social privileges. Homosexuality, even if transitory in this environment, values a larger body biotype ${ }^{32}$. This assessment of feeling good about the body or being satisfied with it deserves attention in view of the limited access to services and health monitoring, associated with resistance to changes in inappropriate behavioral habits that can increase the risk for comorbidities ${ }^{33}$.

Issues related to excess weight are mainly associated with behavioral aspects ${ }^{7,8,25}$. This condition is related to the lifestyle of modern society with the adoption of a dietary pattern linked to a sedentary lifestyle and an unhealthy style ${ }^{34}$. In women deprived of their liberty, the behaviors associated with being overweight were confinement, smoking, unhealthy diets, abusive consumption of the foods offered, the use of laxatives, abstaining from sexual relations and recreational activities offered by the institution and the high consumption of processed foods brought by visitors or received by their cellmates ${ }^{3,7,25}$.

The conditions of the confinement are mainly related to the lack of adequate infrastructure in the prison system, where unhealthy places are common, accompanied by overcrowding, poor hygiene, lack of sufficient structure for health care, which are factors that affect the individual's physical integrity ${ }^{35}$. In the present study, the most reported recreational activities were soccer, burning, stretching, volleyball, walking during sunbathing hours, with the majority (96.8\%) being considered insufficiently active/inactive, 
which can be justified by the lack of infrastructure suitable for carrying out these activities, since the court for these collective actions had been deactivated for weeks, with the sunbathing being carried out in a corridor with restricted dimensions.

Another point to be considered in the present study is joint pain in $54.8 \%$ of the participants, a factor that contributes to inactivity or poor adherence to these activities. A worrying factor is the overweight group in which their totality was classified as insufficiently active or inactive, which in the long run will have a greater chance of becoming obese. Physical inactivity can lead to short-term health problems in this population, such as a sedentary lifestyle, low self-esteem and difficulties in changing life habits, which, if not reversed, can later lead to health complications, such as the emergence of comorbidities and psychopathologies $^{36}$.

In line with these results, a study carried out in other female prisons ${ }^{8}$ points out that the majority of incarcerated women did not perform physical activity in prison, in France $90.9 \%$ of incarcerated women were considered to be inactive or minimally active, with this factor being associated with greater abdominal obesity $(\mathrm{p}<0.05)^{11}$. A study ${ }^{10}$ describes that women reported discouragement and lack of motivation when participating in the only activity offered by the institution, sunbathing, which was not always available to them. Despite the legislation supporting assistance, education, work, recreation and sports practice in prison systems, it is a practice that is still very far from reality, which is characterized by the absence of regular physical activity that can lead to increased idleness and boredom.

Although the institution studied also works with re-socialization actions such as handicrafts, paintings, crochets that serve as a means of acquiring resources from the sale of products made for the purchase of what they need, it is observed that $45.2 \%$ participate in these activities. Most choose to spend most (87.1\%) of their time watching television for a long period that often exceeds 5 hours a day $(63.0 \%)$. The relationship between time in front of the television and excess weight is described ${ }^{37}$. Sitting time watching television is largely responsible for sedentary behavior and disordered food consumption in the general population ${ }^{38}$. Among women, the frequency of watching television between three or more hours is higher when compared to the male population in general $^{39}$.

Food was one of the main complaints of incarcerated women in the present study, in other surveys carried out in prisons in general, they pointed out the scarcity of food offered with few options on the menu, low quality of the food offered, which had a lot of fat, being undercooked and with little seasoning, little palatable flavor, in addition to the presence of insects in meals and the precariousness of lack of water ${ }^{10,31}$.

At the institution of the present study, three daily meals are offered, breakfast, lunch and dinner, the last two basically consisting of rice, beans, meat, pasta, sauteed vegetables and salad. This food is supplied by means of a bidding process, which arrives at the institution in thermal containers and, according to the scale, one to two incarcerated women are responsible for serving the others, being possible to customize the meal according to individual food preference. When analyzing the consumption of vegetables, a high percentage was observed, which can be justified by the fact that the meals offered make these types of food available and, in addition, few receive visits, thus being the only food options for consumption.

Even with the assistance of a nutritionist for the food offered, the unruly and disproportionate practice of consuming preferred foods can contribute to cases of overweight and obesity. It is reinforced that, in order to have a healthy diet, the consumption of macro and micronutrients must be balanced, respecting the recommended amounts ${ }^{40}$. As well, care must be taken as to the conditions for preparing meals in which the use of oil should be used sparingly.

The determining factors for overweight and obesity were identified as aspects of food and nutritional insecurity, namely the lack of access to healthy foods, wrong food choices, large amounts of food eaten, monotonous food without diversity and low nutritional quality ${ }^{10,31}$. When analyzing the situation of the prisons, including this research, it is observed the similarity with the aforementioned descriptions.

Being deprived of freedom, eating behaviors undergo drastic changes. One way to resume to habits before prison is usually accomplished through visitors. Food, cigarettes and hygiene products are the main received items. Among the food products, those industrialized emerged as the most common items brought in due to their unavailability in the prision. The absence of a storage place to perishable food also favors the increase in industrialized products in prisons. The precariousness and quality of the food provided by the institution as reported by some detainees also trigger requests for external food.

Among the limitations of the study, there was an absence of information that could contribute to deepening the results, such as weight before incarceration, pre-prison food history, prenatal history, complementary data related to psycho-emotional aspects. No specific instruments were used to assess and quantify nutrient intake, such as the 24-hour recall or food diary.

It is concluded that despite being a local study, the results were similar to the surveys carried out at the national level, characterized by a vulnerable population with low education, brown race, young, without occupation, information that already induce a situation of food insecurity and nutritional status before imprisonment and that worsens with imprisonment.

In this sense, it is clear that being overweight does not refer only to behavioral factors, it is necessary to know the health situation and the basic conditions of life inside and outside prison. 
The process of incarceration generates and triggers an experience permeated by suffering, being essential the understanding of internal cultural references and the way these women give meaning to everything that happens in that environment. Based on this more in-depth analysis, it will allow assistance subsidies consistent with reality. The need to encourage and carry out more research with this population is emphasized, because through this information it will be possible to make actions and policies that aim to reduce inequities viable, providing better living conditions and greater dignity to this group.

\section{REFERENCES}

1. Dias PC, Henriques $P$, Anjos LA, Burlandy L. Obesity and public policies: the Brazilian government's definitions and strategies. Cad Saude Publica. 2017;33(7):1-11 https://doi.org/10.1590/0102-311X00006016

2. Brasil. Ministerio da Saude, Secretaria de Vigilancia em Saude, Departamento de Vigilancia de Doencas e Agravos nao Transmissiveis e Promocao da Saude. Vigitel Brasil 2016: vigilancia de fatores de risco e protecao para doencas cronicas por inquerito telefonico: estimativas sobre frequencia e distribuicao sociodemografica de fatores de risco e protecao para doencas cronicas nas capitais dos 26 estados brasileiros e no Distrito Federal em 2016. [Internet] Brazil, 2016 [Cited 201 Mar 1] Available from: http://portalarquivos2.saude.gov.br/images/ pdf/2018/marco/02/vigitel-brasil-2016.pdf.

3. Alves RC, Surama E, Davim B, Marie R, Oliveira ME, Ferreira L. Living and health conditions of women on a female prison unit. Rev Nursing. 2016;10(3):958-68.

https://doi.org/10.5205/reuol.8702-76273-4-SM.1003201603

4. Francisco LV, Diez-Garcia RW. Abordagem terapêutica da obesidade: entre conceitos e preconceitos. Demetra. 2015;10(3):705-16.

https://doi.org/10.12957/demetra.2015.16095

5. World Health Organization (WHO). Noncommunicable diseases country profiles 2014. Geneva: WHO, 2014.

6. Gonçalves JTT, Silveira MF, Campos MCC, Costa LHR. Sobrepeso e obesidade e fatores associados ao climatério. Ciênc Saúde Coletiva. 2016;21(4):1145-56.

https://doi.org/10.1590/1413-81232015214.16552015

7. Gonçalves PT, Ribeiro DF, Ventura CAA. O percurso de vida de ex presidiários: reflexões sobre prisão e desenvolvimento humano e social. Rev Perspec Desenvolv Enf Multidim. 2015;3(4):109-41.

8. Assis CL, Vitória EAR. The prevalence of depressive symptoms in women incarcerated of pimenta bueno, Rondônia. Sociais Hum. 2016;29(2):8-20.

https://doi.org/10.5902/2317175817360

9. Munsch S. Study protocol: psychological and physiological consequences of exposure to mass media in young women-an experimental cross-sectional and longitudinal study and the role of moderators. BMC Psychol. 2014;2(1):37

https://doi.org/10.1186/s40359-014-0037-0

10. Audi CAF, Santiago SM, Andrade MGG, Francisco PMSB. Survey on the health conditions of incarcerated women. Saúde Debate. 2016;40(109):112-24.

https://doi.org/10.1590/0103-1104201610909

11. Drach LL, Maher JE, Braun MJ, Murray SL, Sazie E. Substance use, disordered eating, and weight gain: describing the prevention and treatment needs of incarcerated women. J Correct Health Care. 2016;22(2):139-45. https://doi.org/10.1177/1078345816634692

12. Brasil. Ministério da Saúde. Secretaria de Atenção à Saúde. Departamento de Atenção Básica. Coordenação-Geral de Alimentação e Nutrição. Orientações para a coleta e análise de dados antropométricos em serviços de saúde. Brasília: Ministério da Saúde, 2011.

13. World Health Organization (WHO). Physical status: the use and interpretation of anthropometry. Geneva: World Health Organization, 1995

14. Lima NP, Bernardo L, Horta JVSM, Valença MS, Oliveira V, Santos TV. Evolution of overweight and obesity into adulthood, Pelotas, Rio Grande do Sul State, Brazil, 1982-2012. Cad Saúde Pública. 2015;31(9):2017-25.

https://doi.org/10.1590/0102-311X00173814

15. Lagarrigue A, Ajana S, Capuron L, Féart C, Moisan MP. Obesity in French Inmates: gender differences and relationship with mood, eating behavior and physical activity. Plos One. 2017;12(1):e0170413.

https://doi.org/10.1371/journal.pone.0170413

16. Santos RR, Bicalho MAC, Mota P, Oliveira DR, Moraes EN. Obesidade em idosos. Rev Med Minas Gerais. 2013;23(1):64-73. https://doi.org/10.5935/2238-3182.20130011

17. Melo CRM, Reis ES, Silva LCFP, Sola EPS, Chofakian CBN Application of menopausal kupperman index: a cross-sectional study of menopausal women. Espaç Saúde. 2016;17(2):41-50. https://doi.org/10.22421/1517-7130.2016v17n2p41

18. Bezerra IN, Alencar ES. Associação entre excesso de peso e tamanho das porções de bebidas consumidas no Brasil. Rev Saúde Pública. 2018;52(21):1-11.

https://doi.org/10.11606/S1518-8787.2018052000082

19. Destri K, Zanini RV, Assunção MCF. Prevalence of food intake among individuals with hypertension and diabetes in the municipality of Nova Boa Vista, Rio Grande do Sul, Brazil, 2013. Epidemiol Serv Saude. 2017;26(4):857-68. https://doi.org/10.5123/s1679-49742017000400016

20. Brasil. Ministério da Justiça e Segurança Pública. Levantamento Nacional de Informações Penitenciárias (INFOPEN): atualização - junho de 2016. Brasília: 2017. Departamento Penitenciário Nacional

21. Oliveira AF, Araújo Júnior ACS, Cruz JF, Cruz MAF, Santana DS, Rezende KF, et al. Prevalence of overweight and associated factors in a metropolitan area in the Northeast of Brazil. Rev Fac Ciênc Méd Sorocaba. 2018;20(1):38-45. https://doi.org/10.23925/1984-4840.2018v20i1a9

22. Nast M, Oliveira A, Rauber F, Vitolo MR. Excessive gestational weight gain is risk factor for overweight among women. Rev Bras Ginecol Obstet. 2013;35(12):536-40.

23. Vasconcelos CMCS, Costa FS, Almeida PC, Araújo Júnior E, Sampaio HAC. Fatores de risco associados à retenção de peso seis meses após o parto. Rev Bras Ginecol Obstet. 2014;36(5):222-27. https://doi.org/10.1590/S0100-7203201400050007

24. Alves J, Maia AC. Self-Reports of Health before and during. Imprisonment in Female Inmates. Port $J$ Public Health. 2017;35(2):132-40.

https://doi.org/10.1159/000481967 
25. Andrade ALCC, Barbosa APDI, Bagni UV. Imagem corporal no cárcere: percepções de mulheres privadas de liberdade. Demetra. 2018;13;(2):381-93.

https://doi.org/10.12957/demetra.2018.33309

26. Zampier VSB, Silva MH, Jesus RR, Oliveira PP, Jesus MCP, Merighi MAB. Maintenance of tobacco withdrawal by former smokers: a phenomenological study Mantenimiento de la abstinencia del tabaco por los exfumadores: estudio fenomenológico. Rev Gaúcha Enferm. 2018;38(4):e2017-0027. https://doi.org/10.1590/1983-1447.2017.04.2017-0027

27. Bocaleti JMR, Oliveira DGP. Superlotation and the brazilian penitentiary system: is it possible to resocialize? Actio Rev Estud Jurídicos. 2017;27(1):205-17.

28. Minayo MCS, Ribeiro AP. Condições de saúde dos presos do estado do Rio de Janeiro, Brasil. Ciênc Saúde Coletiva. 2016;21(7):2031-40

https://doi.org/10.1590/141381232015217.08552016

29. Pereira DA, Marques MF, Hubner CK, Silva KJF. Depressive symptoms and drug abuse among Incarcerated women in cadeia pública feminina de Votorantim/SP. Rev Fac Ciênc Med Sorocaba. 2014;16(2):71-75.

30. Soares IR, Cenci CMB, Oliveira LRF. Mães no cárcere: percepção de vínculo com os filhos. Estud Pesq Ppsicol. 2016;16(1):27-45.

31. Gates ML, Bradford RK. The Impact of incarceration on obesity: are prisoners with chronic diseases becoming overweight and obese during their confinement? J Obesity. 2015;2015:e532468

https://doi.org/10.1155/2015/532468

32. Francisco RS. Homossexualidade feminina: o caso do presídio feminino Carlos Tinoco da Fonseca em Campos dos Goytacazes. Vértices. 2015;17(1):7-21.

https://doi.org/10.5935/1809-2667.20150001
33. Nascimento CAD, Bezerra SMMS, Angelim EMS. Vivência da obesidade e do emagrecimento em mulheres submetidas à cirurgia bariátrica. Estud Psicol. 2013;18(2):193-201.

34. Nascimento TS, Mussi FC, Palmeira CS, Santos CAT, Santos MA Factors related to leisure-time physical inactivity in obese women. Acta Paul Enferm. 2017:30(3):308-15. https://doi.org/10.1590/1982-0194201700047

35. Martins ELC, Martins LG, Silveira AM, Melo EM. The contradictory right to health of people deprived of liberty: the case of a prison in Minas Gerais, Brazil. Saúde Soc. 2014;23(4):1222-34. https://doi.org/10.1590/S0104-12902014000400009

36. Souza IL, Francisco PMSB, Lima MG, Barros MBA. Level of physical inactivity in different domains and associated factors in adults: Health Survey in Campinas city (ISACamp 2008/2009), São Paulo state, Brazil. Epidemiol Serv Saúde. 2014;23(4);623-34. https://doi.org/10.5123/S1679-49742014000400004

37. Lowry R, Associations of Physical Activity and Sedentary Behaviors with Dietary Behaviors among US High School Students. J Obesity. 2015:e876524. https://doi.org/10.1155/2015/876524

38. Marsh S, Mhurchu CN, Maddison R. The non-advertising effects of screen-based sedentary activities on acute eating behaviours in children, adolescents, and young adults. A systematic review. Appetite. 2013;71:259-73. https://doi.org/10.1016/j.appet.2013.08.017

39. Mielke GI, Silva ICM, Owen N, Hallal PC. Brazilian adults' sedentary behaviors by life domain: population-based study. Plos One. 2014;9(3):e91614 https://doi.org/0.1371/journal.pone.0091614

40. Brasil. Ministério da Saúde. Departamento de Atenção Básica. Guia alimentar para a população brasileira. Brasília: Ministério da Saúde, 2014 